\title{
Ecophysiological leaf traits of native and exotic palm tree species under semi-arid conditions
}

\author{
Deborah Oliveira, Maria Medeiros, Silvia Pereira, Marciel Oliveira, Gabriella Frosi, Emília Arruda, \\ Mauro Santos* \\ Universidade Federal de Pernambuco - Departamento de Botânica - Recife (PE), Brasil.
}

\begin{abstract}
The main goal of this study was to evaluate the performance of two palm species under semi-arid conditions during the rainy and dry periods: the semi-arid native Syagrus coronata and a native to tropical America, Acrocomia aculeata. The leaf water potential, gas exchange, leaf soluble sugars, starch, free amino acids, total soluble protein content and morphological traits were measured. The highest leaf water potential and $\mathrm{CO}_{2}$ assimilation values in both species were achieved during the rainy period. In response to the low soil moisture content during the dry period, gas exchange decreased 72 and $92 \%$ in S. coronata and A. aculeata, respectively,
\end{abstract}

when compared with values from rainy period. As evergreen plants, both species maintained intact leaf photosynthetic pigment contents during the rainy and dry periods. Other important traits for drought tolerance are larger adaxial surface hypoderm and cuticle found in both species with higher stomatal density on the abaxial leaf surface. When comparing the species, S. coronata exhibited lower sensitivity to low water availability, showing higher $\mathrm{CO}_{2}$ assimilation and water use efficiency.

Key words: Acrocomia aculeata, evergreen species, gas exchange, Syagrus coronata, water deficit.

\section{INTRODUCTION}

The few ecophysiology studies conducted to investigate palms describe tolerant species to drought stress (Oliveira et al. 2002; Gomes and Prado 2007; Suresh et al. 2012; Medeiros et al. 2015). There are many palm species with economic importance, such as Elaeis guineensis or oil palm (Suresh et al. 2012), Cocos nucifera or coconut palm (Gomes and Prado 2007), Bactris gasipaes or peach palm (Oliveira et al. 2002) and Acrocomia aculeata or macaw palm (Pires et al. 2013), most of them found in tropical rain forests.

The Northeastern semi-arid region of Brazil includes the most endangered ecosystem, Caatinga, which is a seasonally dry tropical forest (Santos et al. 2014). Thus, plant species with economic potential could have two features: they should improve the quality of life of the local people and be important for biological conservation. In addition to anthropic threats, Caatinga must adapt to changes in climate (Santos et al. 2014). The forecast for semi-arid regions worldwide is an increase in the frequency of drought events, which may represent a threat for several species (Donohue et al. 2013). Under drought stress, the water use efficiency of the peach palm, a native Brazilian palm, increases as a consequence of decreases in stomatal conductance and transpiration rate with marginal changes in $\mathrm{CO}_{2}$ assimilation (Oliveira et al. 2002). The same performance has been observed for the oil palm exposed to a water deficit under field conditions (Suresh et al. 2012).

Data about the ecophysiology of palm trees are still scarce and often obtained under environmental conditions different from those found in semi-arid region. Thus, this work evaluated some ecophysiological aspects of two American palm species - Acrocomia aculeata and Syagrus coronata - under field conditions. The first species is a palm tree native to the tropical Americas. It may be found in different Brazilian ecosystems, including degraded areas (Motta et al. 2002; Pires et al. 2013). In addition, the fruits of this species have large oil content (Coimbra and Jorge 2012). 
The second species, S. coronata, is a native species to semi-arid regions in the northeast of Brazil, has high oil content and is useful for the local population (Rufino et al. 2008). Under controlled conditions, this species exhibits robust photosynthetic drought tolerance (Medeiros et al. 2015).

The aim of this study was to increase the knowledge of the two species under semi-arid conditions. We expect that $S$. coronata present less sensitivity of photosynthetic metabolism to dry conditions as compared with the semiarid exotic palm tree $A$. aculeata. To test this hypothesis, we measured the gas exchange, leaf carbon balance components and leaf anatomical parameters during the rainy and dry periods. The effects of environmental changes on leaf metabolism are discussed.

\section{MATERIAL AND METHODS Environmental conditions and plant material}

The experiment was carried out in the Northeastern Brazil ( $8^{\circ} 46^{\prime} \mathrm{S}$ and $36^{\circ} 37^{\prime} \mathrm{O}$ ). The climate, according to Köppen-Geiger, is tropical with a dry period (As). The rainy period starts in January/February and ends in September. This area is prone to droughts, with an average rainfall of $550 \mathrm{~mm}$ per year. The palm trees Acrocomia aculeata (Jacq) Lodd. ex Martius and Syagrus coronata Mart. Becc. were 2.5 and 14 years old, respectively. Because of this difference in age, we show and discuss the results without direct comparisons. Plants of $S$. coronata native to the area were spaced around $10 \mathrm{~m}$ from each other, whereas plants of $A$. aculeata were spaced $7 \mathrm{~m}$ within and between planting lines. Five trees of each species were sampled on four different dates between May 2011 and
November 2012. The sample data were grouped in the "rainy period" (May 2011) and "dry period" (November 2011, May 2012 and November 2012), according to the classification of the water content for the soil in this study (sandy loam), where the humidity below $10 \%$ is considered the permanent wilting point (Figures 1a,b).

During the evaluations, the rainfall was $297 \mathrm{~mm}$ in May 2011 (rainy period), $25 \mathrm{~mm}$ in November 2011 (dry period), $36 \mathrm{~mm}$ in May 2012 (dry period) and $63 \mathrm{~mm}$ in November 2012 (dry period), resulting in a total of 297 and $124 \mathrm{~mm}$ in rainy and dry periods defined herein, respectively. During the measurements, the photosynthetic photon flux density during the rainy period was 800 and $2,000 \mu \mathrm{mol} \cdot \mathrm{m}^{-2} \cdot \mathrm{s}^{-1}$ in the morning and afternoon, respectively. In the dry period, the morning and afternoon averages were 1,200 and $1,800 \mu \mathrm{mol} \cdot \mathrm{m}^{-2} \cdot \mathrm{s}^{-1}$, respectively.

\section{Soil and leaf water status}

We measured the soil moisture on the same days that gas exchange was measured. To measure soil relative water content (SRWC), the $30-\mathrm{cm}$ depth soil samples were collected in areas around the five individuals of each species. The soil was stored in a tightly sealed plastic bag and weighed fresh weight (FW) in the laboratory. The soil was then dried under a forced air oven at $80{ }^{\circ} \mathrm{C}$ until constant weight dry weight (DW). SRWC was calculated as follows: SRWC $(\%)=(\mathrm{FW}-\mathrm{DW}) / \mathrm{DW} \times 100$.

The leaf water status $\left(Y_{1}\right)$ was measured at 08:00 and 14:00 on the same days that gas exchange measurements were obtained. Fully expanded and healthy leaflets of five individuals of each species were used. The measurements
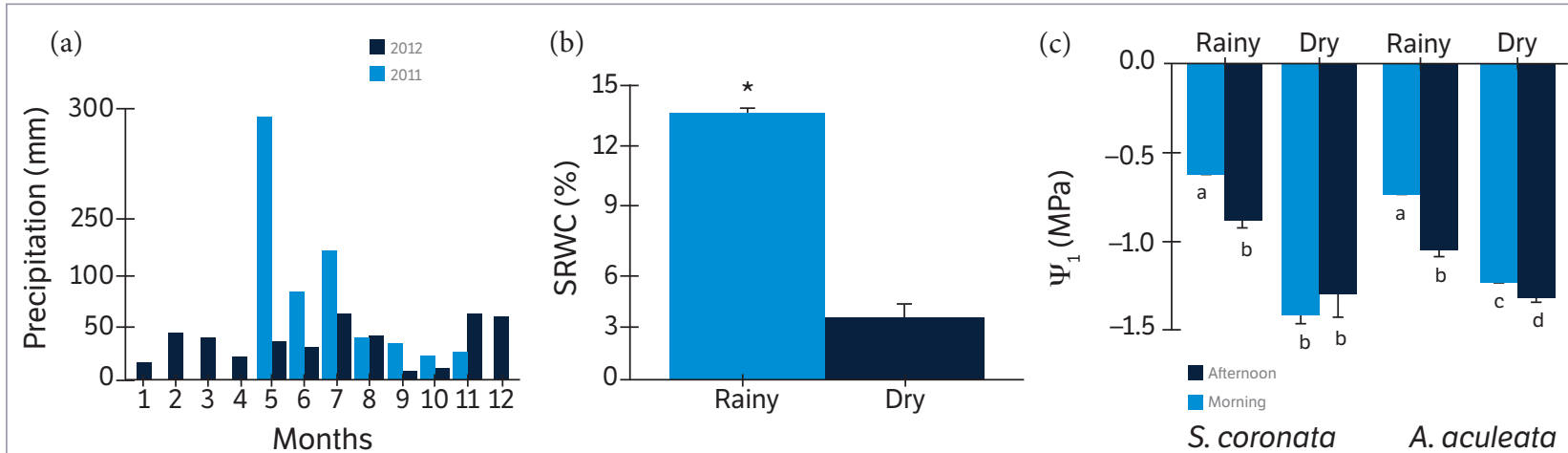

Values represent the average ( \pm SE) of replicates ( $n=5$ or 15 , for rainy and dry periods, respectively). Different letters denote significant differences according to the Newman-Keuls test with a significance level of $5 \%$ between mean values within each species.

Figure 1. (a) Monthly total precipitation; (b) Soil relative water content (SRWC) in Caetés (Pernambuco, Brazil); (c) Leaf water potential ( $Y$ ) of $S$. coronata and $A$. aculeata measured during rainy and dry periods. 
were performed using a pressure chamber (model 3035, Soil Moisture Equipment Corp., Santa Barbara, CA, USA) according to Scholander et al. (1964).

\section{Gas exchange}

In a completely randomized design, five plants per species were selected for physiological measurements - net $\mathrm{CO}_{2}$ assimilation $\left(P_{N}\right)$, stomatal conductance $\left(g_{s}\right)$, and transpiration $(E)$ - performed in fully expanded and healthy leaflets using an infra-red gas analyser (IRGA, LC-pro, ADC, UK). The leaves were mature and fully expanded but not senescent; moreover, they were intact and healthy. The measurements were performed in the morning (between 08:00 and 09:00) and afternoon (between 13:00 and 14:00). Using these data, we calculated the water use efficiency $\left(\mathrm{WUE}=P_{N} / E\right)$. The air vapour pressure deficit (VPD) was measured with a portable thermo-hygrometer. VPD was $0.3 \mathrm{kPa}$ (morning) and $0.5 \mathrm{kPa}$ (afternoon) during the rainy period, whereas it varied between $0.6 \mathrm{kPa}$ (morning) and $1.3 \mathrm{kPa}$ (afternoon), during the dry period.

\section{Leaf biochemical analyses}

Samples from five individuals per species were collected between 14:00 and 15:00. Immediately after the measured gas exchange, leaves were frozen in liquid nitrogen and stored at $-20^{\circ} \mathrm{C}$. For ethanolic extraction, we used $50 \mathrm{mg}$ of leaf tissue. Soluble sugars (SS) were measured according to Dubois et al. (1956) using D (+)-glucose as standard. This same ethanolic extract was used to measure the free amino acid (FAA) content (Moore and Stein 1948) using a $1 \mathrm{mM}$ solution of glycine, glutamic acid, phenylalanine and arginine as standard. The insoluble fraction from the extraction of SS was used to determine the starch content. The pellet was hydrolysed for one hour with ten units of amyloglucosidase, and the resulting sugars were analysed a second time (Dubois et al. 1956) using D (+)-glucose as standard. To extract the leaf total soluble protein content (TSP), we used $100 \mathrm{mg}$ of leaf tissue from S. coronata and 100 and $50 \mathrm{mg}$ of leaf tissue from A. aculeata for the dry and rainy periods, respectively. An aliquot of the extract was used for protein quantification according to the Bradford method (1976) at a wavelength of $595 \mathrm{~nm}$ using bovine serum albumin as standard. Photosynthetic pigments (chlorophyll $a$, chorophyll $b$ and carotenoids) were extracted from $100 \mathrm{mg}$ of leaf tissue from S. coronata and $50 \mathrm{mg}$ of leaf tissue from A. aculeata. According to the methodology proposed by Lichtenthaler (1987), the samples were macerated in $1 \mathrm{~mL}$ of acetone (80\%) with $\mathrm{CaCO}_{3}$ to avoid chlorophyllase activity. The readings were performed using a spectrophotometer at $470,646.8$ and $663.2 \mathrm{~nm}$. Additionally, the non-specific absorbance at $710 \mathrm{~nm}$ was recorded to correct for colour, turbidity and contaminating compounds.

\section{Leaf anatomical analyses}

We collected the same leaves in which gas exchange was measured in May and November 2012 (dry period). For the transverse sections of S. coronata and A. aculeata, we used the fully expanded leaflets located in the middle portion of the rachis of six individuals. The leaflets collected from S. coronata were frozen in liquid nitrogen, and then $18-\mu \mathrm{m}$ sections were obtained using a rotatory cryomicrotome (Zeiss, model Hyrax C25) at $-25^{\circ} \mathrm{C}$. For $A$. aculeata, the collected leaflets were fixed in FAA 70 and maintained in $70 \%$ ethanol solution. The transverse sections were then sectioned by hand, clarified using $50 \%$ sodium hypochlorite solution and bathed with deionized water until complete removal of the solution (Kraus and Arduin 1997). All of the sections were subsequently stained with safranin-astra blue (Kraus and Arduin 1997). For epidermal dissociation, the samples were submitted to Franklin (1945) solution and stored in a kiln at $80^{\circ} \mathrm{C}$ for $48 \mathrm{~h}$ (A. aculeata) and $72 \mathrm{~h}$ (S. coronata). The epidermis was bathed with deionized water until complete removal of the solution and then stained with $1 \%$ safranin. Photomicrographs were obtained using a Leica DM 500 light photomicroscope. For the quantitative evaluation of leaf samples, the image analysis software IMAGEPROßPLUS was used. From the six individuals of each species, we analysed 48 and 60 randomly selected microscopic fields of view for the transverse sections and paradermal sections (adaxial and abaxial epidermis), respectively. We measured the thickness of the mesophyll, epidermis, hypodermis and cuticle in the transverse sections and of the dissociated epidermis. In addition, we measured the length and thickness of the stomata and the stomatal density (SD; number of stomata / unit area).

\section{Statistical analyses}

The data obtained for SRWC, $\Psi_{1}$, gas exchange and the biochemical analysis were subjected to the analysis of 
variance (ANOVA), and the averages were compared using the Student-Newman-Keuls test at a significance level of 5\%. To compare the anatomical variables, Student's t-test was used with a 5\% threshold for significance. All statistical analyses were carried out using STATISTICA 7.0 software.

\section{RESULTS AND DISCUSSION}

The soil moisture was $14 \%$ during the rainy period and $3 \%$ during the dry period (Figure $1 \mathrm{~b}$ ). The $\Psi_{1}$ of S. coronata did not vary between the morning and afternoon during the rainy period, decreasing during the dry period to an average of -1.4 MPa without differences between diurnal periods. In the rainy period, the $\Psi_{1}$ for $A$. aculeata was -0.7 and $-1.0 \mathrm{MPa}$ in the morning and afternoon, respectively. The average $\Psi_{1}$ during the dry period was -1.2 and $-1.3 \mathrm{MPa}$ in the morning and afternoon, respectively (Figure 1c). The leaf water potential in S. coronata plants showed a high diurnal stability in both periods at times of high and low VPD. On the other hand, the values were reduced in both species under high VPD in the afternoon. This oscillation was followed by $g_{s}$, but not by $\mathrm{CO}_{2}$ assimilation in both species during the rainy period (Figures 2a,b).

In the rainy period, the $g_{s}$ for $S$. coronata was 65 and $48 \mathrm{mmol} \cdot \mathrm{m}^{-2} \cdot \mathrm{s}^{-1}$ in the morning and afternoon, respectively. In the dry period, these values decreased by $97 \%$ and there was no difference between morning and afternoon (Figure 2a). The average $P_{N}$ of $S$. coronata during the rainy and dry periods was 10 and $2 \mu \mathrm{mol} \cdot \mathrm{m}^{-2} \cdot \mathrm{s}^{-1}$, respectively (Figure $2 \mathrm{~b}$ ). During the rainy period, the average rate of transpiration in the morning was $0.7 \mathrm{mmol} \cdot \mathrm{m}^{-2} \cdot \mathrm{s}^{-1}$, which increased in the afternoon to $1.2 \mathrm{mmol} \cdot \mathrm{m}^{-2} \cdot \mathrm{s}^{-1}$ in $S$. coronata (Figure 2c). During the dry period, there were no differences in $E$ between the diurnal periods. The WUE differed according to the water availability; the average value was $10 \mu \mathrm{mol} \mathrm{CO} \cdot{ }_{2} \cdot \mathrm{mmol}^{-1} \mathrm{H}_{2} \mathrm{O}$, while the average WUE increased to $1,520 \mu \mathrm{molCO}_{2} \cdot \mathrm{mmol}^{-1} \mathrm{H}_{2} \mathrm{O}$ in the dry season (Figure 2d).

The average $g_{s}$ values for $A$. aculeata during the rainy period were $155 \mathrm{mmol} \cdot \mathrm{m}^{-2} \cdot \mathrm{s}^{-1}$ in the morning followed by a decrease in the afternoon to $22 \mathrm{mmol} \cdot \mathrm{m}^{-2} \cdot \mathrm{s}^{-1}$ (Figure 2a). During the dry period, there was no diurnal change in $g_{s}$. The net photosynthesis rate differed between the water availability periods but not between the diurnal periods. Significant differences were found in $E$ when compared the diurnal periods in the rainy period. During the rainy period, the average WUE was $15 \mu \mathrm{mol} \mathrm{CO} \cdot \mathrm{mmol}^{-1} \mathrm{H}_{2} \mathrm{O}$, while the average WUE was $629 \mu \mathrm{mol} \mathrm{CO} \cdot \mathrm{mmol}^{-1} \mathrm{H}_{2} \mathrm{O}$ in the dry period for A. aculeata.

The same trends of reduced $g_{s}$ and $P_{N}$ during periods of low water availability have also been observed in other species of palm (Calbo and Moraes 2000; Oliveira et al. 2002), in which the reduction of $g_{s}$ leads to decrease in $E$ more than in $P_{N^{*}}$ This phenomenon causes an immediate increase in WUE, as observed in the oil palm (Suresh et al. 2012). During the dry period, WUE increased in S. coronata and A. aculeata; $S$. coronata had the highest WUE values during periods with a rainfall shortage, demonstrating a greater tolerance to semi-arid environments. The relationship between $g_{s}$ and $P_{N}$ differs among the various palm species, with a direct relationship being observed in peach palm trees (Oliveira et al. 2002; Tucci et al. 2010). In S. coronata and A. aculeata, the $P_{N}$ and

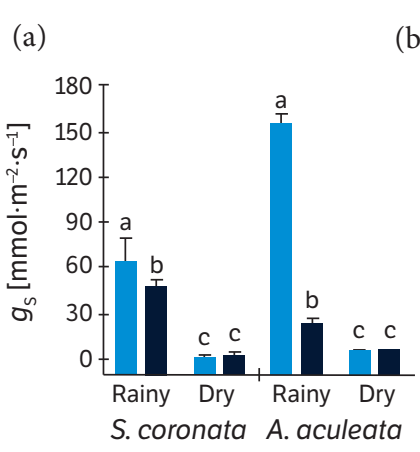

(b)

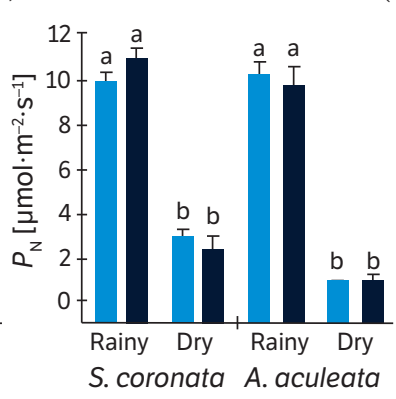

(c)

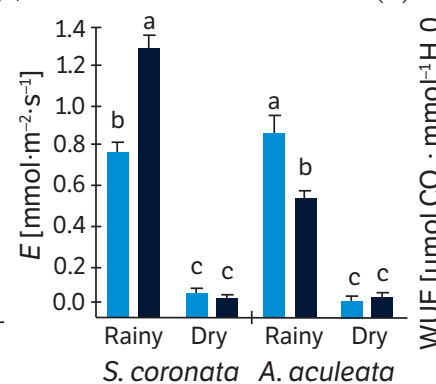<smiles>[CH]C</smiles>

Morning

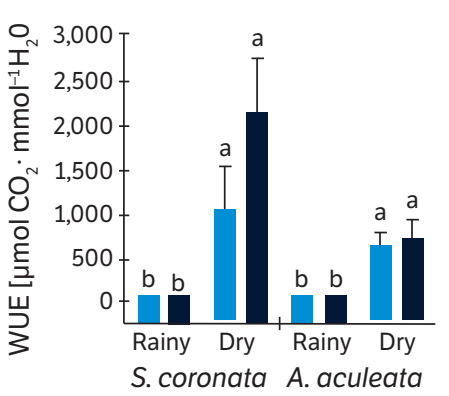

Values represent the average ( \pm SE) of replicates ( $n=5$ or 15 , for rainy and dry periods, respectively). Different letters denote significant differences according to the Newman-Keuls test with a significance level of $5 \%$ between mean values within each species.

Figure 2. Diurnal changes in leaf gas exchange of $S$. coronata and $A$. aculeata plants under field conditions in Caetés (Pernambuco, Brazil) measured under rainy and dry periods: (a) Stomatal conductance $\left(g_{s}\right)$; (b) Net $\mathrm{CO}_{2}$ assimilation $\left(P_{N}\right)$; (c) Transpiration $(E)$; (d) Water use efficiency (WUE). 
$E$ values did not follow $g_{s}$ under high soil moisture content. When VPD increased during the afternoon, the $g_{s}$ values decreased; however, a decrease in $P_{N}$ and $E$ was not detected in both species. This phenomenon resulted in a reduction of leaf water potential in the afternoon in both species. Under low soil moisture, reduced $g_{s}$ during the day decreased $P_{N}$ and $E$ and strongly increased WUE in S. coronata. Some of the features of evergreen species must be considered, such as the maintenance of photosynthetic pigments and leaf anatomy characteristics, particularly the epidermis. Furthermore, one might expect a higher gain of biomass of S. coronata during the dry period as compared to A. aculeata, a hypothesis based on photosynthetic performance under water limiting conditions.

The levels of SS in S. coronata were influenced by water availability. In the rainy period, the average SS was 709 $\mathrm{mmol} \cdot \mathrm{kg}^{-1} \mathrm{DW}$, while SS average was $421 \mathrm{mmol} \cdot \mathrm{kg}^{-1} \mathrm{DW}$ (Table 1) in the dry period. Regarding the other biochemical parameters, no significant differences between evaluated periods were observed. The content of SS in A. aculeata during the rainy period was $960 \mathrm{mmol} \cdot \mathrm{kg}^{-1} \mathrm{DW}$, whereas it was $527 \mathrm{mmol} \cdot \mathrm{kg}^{-1} \mathrm{DW}$ during the dry period (Table 1 ). No differences in starch content were observed between the rainy and dry periods (Table 1). The leaves of $A$. aculeata accumulated FAA and TSP during the dry period. The photosynthetic pigments were not significantly affected by water availability, with leaf chlorophyll $a$ content varying from 1.4 to 1.5 and 3.7 to $4.0 \mathrm{~g} \cdot \mathrm{kg}^{-1} \mathrm{DW}$ in S. coronata and A. aculeata, respectively. The leaf chlorophyll $b$ content varied from 0.4 to 0.5 and 1.2

Table 1. Leaf biochemical variables in S. coronata and A. aculeata plants under field conditions in Caetés (Pernambuco, Brazil) evaluated during rainy and dry periods.

\begin{tabular}{cccc}
\multirow{2}{*}{ Variables } & Period & \multicolumn{2}{c|}{ Species } \\
\cline { 2 - 4 } & & S. coronata & A. aculeata \\
\cline { 2 - 4 } SS & Rainy & $709 \pm 33^{\mathrm{a}}$ & $960 \pm 34^{\mathrm{a}}$ \\
\cline { 2 - 4 } & Dry & $421 \pm 34^{\mathrm{b}}$ & $527 \pm 39^{\mathrm{b}}$ \\
\hline \multirow{2}{*}{ Starch } & Rainy & $274 \pm 20^{\mathrm{a}}$ & $399 \pm 35^{\mathrm{a}}$ \\
\cline { 2 - 4 } & Dry & $255 \pm 16^{\mathrm{a}}$ & $374 \pm 16^{\mathrm{a}}$ \\
\hline \multirow{2}{*}{ FAA } & Rainy & $43 \pm 2^{\mathrm{a}}$ & $65 \pm 4^{\mathrm{b}}$ \\
\cline { 2 - 4 } & Dry & $47 \pm 5^{\mathrm{a}}$ & $166 \pm 16^{\mathrm{a}}$ \\
\hline \multirow{2}{*}{ TSP } & Rainy & $18 \pm 1^{\mathrm{a}}$ & $20 \pm 1^{\mathrm{b}}$ \\
\cline { 2 - 4 } & Dry & $20 \pm 3^{\mathrm{a}}$ & $45 \pm 8^{\mathrm{a}}$ \\
\hline
\end{tabular}

Values represent the average of replicates ( $n=5$ or $15, \pm S E$, for rainy and dry seasons, respectively). Different letters denote significant differences according to the Newman-Keuls test with a significance level of $5 \%$ between periods within each species. SS = Soluble sugars $\left(\mathrm{mmol} \cdot \mathrm{kg}^{-1} \mathrm{DW}\right)$; Starch (mmol glucose $\left.\cdot \mathrm{kg}^{-1} \mathrm{DW}\right) ; \mathrm{FAA}=$ Free amino acids $\left(\mathrm{mmol} \cdot \mathrm{kg}^{-1} \mathrm{DW}\right) ; \mathrm{TSP}=$ Total soluble proteins $\left(\mathrm{g} \cdot \mathrm{kg}^{-1} \mathrm{DW}\right)$. to $1.4 \mathrm{~g} \cdot \mathrm{kg}^{-1} \mathrm{DW}$ in $S$. coronata and A. aculeata, respectively, whereas the leaf carotenoids content varied from 0.5 to 0.6 and 1.0 to $1.3 \mathrm{~g} \cdot \mathrm{kg}^{-1} \mathrm{DW}$.

In fact, to maintain photosynthetic activity under conditions of drought, leaves must show intact photosynthetic pigment contents, as observed for both species in the present study. Under semi-arid conditions, the leaves are exposed on a daily basis to a high light incidence, high air VPD and irregular soil moisture content. Thus, the majority of the species are deciduous, with leaves being lost during the dry period (Santos et al. 2014). Nevertheless, some of the species are evergreen and present important mechanisms to withstand the semi-arid abiotic stress. Under drought stress, oil palms trees do not exhibit any effects of drought on the photochemical machinery, in part due to the maintenance of high photosynthetic pigment contents and efficient photoprotection mechanisms (Suresh et al. 2012). S. coronata potted plants exposed to controlled drought stress showed a decrease in photochemical parameters only after 20 days of water withholding. However, non-photochemical quenching in stressed plants increased at the beginning of the fifth day of water deficit. After four days of rehydration, all photochemical parameters displayed values similar to those of well-watered control plants (Medeiros et al. 2015). This performance suggests that the photosynthetic machinery of $S$. coronata has robust protection mechanisms against drought damage.

The leaf content of some primary carbon metabolites could function as a protective mechanism for the photosynthetic machinery against reactive oxygen species (Keunen et al. 2013). The increase in SS during the rainy period in both species is justified by high $P_{N}$, which decreased for both species in dry period. Thus, the balance between the carbon gain through photosynthesis and the use of assimilates was affected during dry period conditions, leading to changes in sugar content (Pinheiro and Chaves 2011). The content of other compatible solutes, such as FAA, also increased as a consequence of drought only in A. aculeata (Chen and Murata 2002). The maintenance of photosynthetic activity even during periods of low rainfall is an advantage for evergreen species compared with deciduous species. In a previous study, high FAA and sugar leaf content induced by water deficit in some coconut genotypes were associated with osmotic adjustments (Bai and Rajagopal 2000). However, those potential effects of FAA and SS as osmolites for maintaining leaf water status were not found herein as both species presented decreases in leaf water potential in the dry period. 
The anatomical sections of both species revealed a thick cuticle and uniseriate epidermis. There were stomata on both leaf surfaces. The adaxial surface contained the leaflet veins located slightly below the level of the other epidermal cells. In contrast, the abaxial surface lacked stomata on the veins. The analysis of other characteristics in the cross-sections revealed differences between the adaxial and abaxial surfaces. Because there are no stomata on the adaxial leaf surface in either species, the stomatal density and the length and width of the stomata were only recorded in the abaxial region (Table 1).

In tropical environments, the tolerance of species to reduced water availability results from different factors. The control of water loss in leaves can occur either through the stomata or epidermal tissue, which is especially prevalent in evergreen species. Such evergreen species are the minority among the native species of the Brazilian semi-arid region. The thick cuticle of the epidermis in Syagrus genus is related to the protection of such plants against desiccation because these species grow in environments that are subjected to drought stress (Leite and Scatena 2001). Although previously considered amphistomatic, the highest concentration of stomata in S. coronata and A. aculeata is found on the abaxial epidermis (Table 2). This localization appears to be protective for the stomata because the upper surface is exposed to direct sunlight due to leaf orientation. The closing movements of leaves in both species could reduce the loss of water and the incidence of sunlight on leaf surface while enabling partially opened stomata to support gas exchange under dry conditions.

\section{CONCLUSION}

Gas exchange in A. aculeata and S. coronata was shown under semi-arid conditions, and the highest values were observed during the rainy period. During the dry period
Table 2. Leaf anatomical variables for S. coronata and A. aculeata plants under field conditions in Caetés (Pernambuco, Brazil) during the dry period.

\begin{tabular}{|c|c|c|c|}
\hline Variables & Surface & S. coronata & A. aculeata \\
\hline \multirow{2}{*}{$\begin{array}{c}\text { Epidermal } \\
\text { thickness }(\mu \mathrm{m})\end{array}$} & Adaxial & $4.5 \pm 0.1^{a}$ & $10.5 \pm 0.3^{a}$ \\
\hline & Abaxial & $3.7 \pm 0.1^{b}$ & $11.3 \pm 0.4^{a}$ \\
\hline \multirow{2}{*}{$\begin{array}{l}\text { Hypodermis } \\
\text { thickness }(\mu \mathrm{m})\end{array}$} & Adaxial & $7.3 \pm 0.2^{a}$ & $27.9 \pm 1.4^{a}$ \\
\hline & Abaxial & $5.4 \pm 0.2^{b}$ & $17.9 \pm 0.4^{b}$ \\
\hline \multirow{2}{*}{$\begin{array}{l}\text { Cuticle thickness } \\
\qquad(\mu \mathrm{m})\end{array}$} & Adaxial & $4.4 \pm 0.2^{a}$ & $5.8 \pm 0.36^{a}$ \\
\hline & Abaxial & $3.4 \pm 0.1^{b}$ & $4.6 \pm 0.3^{b}$ \\
\hline \multirow{2}{*}{$\begin{array}{l}\text { Stomatal density } \\
\quad\left(0.02 \mathrm{~mm}^{2}\right)\end{array}$} & Adaxial & 0.0 & 0.0 \\
\hline & Abaxial & $61.0 \pm 1.0$ & $73.0 \pm 2.0$ \\
\hline $\begin{array}{c}\text { Mesophyll } \\
\text { thickness }(\mu \mathrm{m})\end{array}$ & & $159.1 \pm 3.0$ & $198.8 \pm 4.0$ \\
\hline $\begin{array}{c}\text { Stomatal } \\
\text { height }(\mu \mathrm{m})\end{array}$ & & $15.4 \pm 0.2$ & $17.1 \pm 0.1$ \\
\hline $\begin{array}{c}\text { Stomatal } \\
\text { width }(\mu \mathrm{m})\end{array}$ & & $6.0 \pm 0.1$ & $6.9 \pm 0.1$ \\
\hline
\end{tabular}

Values represent the average of replicates ( $n=48, \pm$ SE). Different letters denote significant differences between leaf surfaces, according to the Newman-Keuls test with a significance level of $5 \%$.

with low soil moisture content, the stomatal conductance decreased similarly to the transpiration rate when compared to the rainy period. Therefore, the $\mathrm{CO}_{2}$ assimilation did not follow the same pattern, and the water use efficiency increased in both species, especially in S. coronata. Herein, the species did not show large differences in drought stress tolerance, which contradicts our initial hypothesis. However, S. coronata showed higher $\mathrm{CO}_{2}$ assimilation under dry conditions, with same leaf water potential and stomatal conductance of A. aculeata. This performance led to higher water use efficiency of $S$. coronata. These traits are essential for perennial species with economic importance growing in semi-arid regions, and this report is the first step towards the understanding of S. coronata performance in such environment. A long-term study under these conditions may ultimately show a species with several mechanisms to tolerate low water availability.

\section{REFERENCES}

Bai, K. V. K. and Rajagopal, V. (2000). Osmotic adjustment as a mechanism for drought tolerance in coconut (Cocos nucifera L.). Indian Journal of Plant Physiology, 5, 320-323.

Bradford, M. (1976). Rapid and quantitative method for quantitation of microgram quantities of protein utilizing the principle of protein-dye binding. Annals of Biochemistry, 72, 284-252. http://dx.doi.org/10.1016/0003-2697(76)90527-3.

Calbo, M. E. R. and Moraes, J. A. P. V. (2000). Water deficiency effect on Euterpe oleracea plants. Brazilian Journal of Botany, 23, 225-230. http://dx.doi.org/10.1590/S0100-84042000000300001. 
Chen, T. H. H. and Murata, N. (2002). Enhancement of tolerance of abiotic stress by metabolic engineering of betaines and other compatible solutes. Current Opinion in Plant Biology, 5, 250-257. http://dx.doi.org/10.1016/S1369-5266(02)00255-8.

Coimbra, M. C. and Jorge, N. (2012). Fatty acids and bioactive compounds of the pulps and kernels of Brazilian palm species, guariroba (Syagrus oleraces), jerivá (Syagrus romanzoffiana) and macaúba (Acrocomia aculeata). Journal of the Science of Food and Agriculture, 92, 679-684. http://dx.doi.org/10.1002/jsfa.4630.

Donohue, R. J., Roderick, M. L., McVicar, T. R. and Farquhar, G. D. (2013). $\mathrm{CO}_{2}$ fertilization has increased maximum foliage cover across the globe's warm, arid environments. Geophysical Research Letters, 40, 3031-3035. http://dx.doi.org/10.1002/grl.50563.

Dubois, M., Gilles, K. A., Hamilton, J. K., Reders, P. A. and Smith, F. (1956). Colorimetric method for determination of sugars and related substances. Annals of Chemistry, 28, 350-356. http://dx.doi.org/ 10.1021/ac60111a017.

Franklin, G. L. (1945). Preparation of thin sections of synthetic resins and wood-resin composites and a new macerating method for wood. Nature, 155, 51. http://dx.doi.org/10.1038/155051a0.

Gomes, F. P. and Prado, C. H. B. A. (2007). Ecophysiology of coconut palm under water stress. Brazilian Journal of Plant Physiology, 19, 377-391. http://dx.doi.org/10.1590/S1677-04202007000400008.

Keunen, E., Peshev, D. Vangronsveld, J., Ende, W. V. D. and Cuypers, A. (2013). Plant sugars are crucial players in the oxidative challenge during abiotic stress: extending the traditional concept. Plant, Cell and Environment, 36, 1242-1255. http://dx.doi.org/10.1111/pce.12061.

Kraus, J. E. and Arduin, M. (1997). Manual básico de métodos em morfologia vegetal. Rio de Janeiro: Edur-RJ.

Leite, K. R. B. and Scatena, V.L. (2001). Anatomy of the leaf segments of the species of Syagrus Mart. (Arecaceae) of the Chapada Diamantina, Bahia, Brazil. Sitientibus Série Ciências Biológicas, 1, 3-14.

Lichtenthaler, H. K. (1987). Chlorophylls and carotenoids: pigments of photosynthetic biomembranes. Methods in Enzymology, 148, 350-382. http://dx.doi.org/10.1016/0076-6879(87)48036-1.

Medeiros, M. J., Oliveira, D. S., Oliveira, M. T., Willadino, L., Houllou, L. and Santos, M. G. (2015). Ecophysiological, anatomical and biochemical aspects of in vitro culture of zygotic Syagrus coronata embryos and of young plants under drought stress. Trees, 29, 12191233. http://dx.doi.org/10.1007/s00468-015-1202-7.
Moore, S. and Stein, W. H. (1948). Photometric ninhydrin method for use in the chromatography of amino acids. Journal of Biological Chemistry, 176, 367-388.

Motta, P. D., Curi, N., Oliveira Filho, A. T. and Gomes, J. B. V. (2002). Macaw palm occurrence in Minas Gerais: relationship with climatic attributes, soil and vegetation. Pesquisa Agropecuária Brasileira, 37, 1023-1031. http://dx.doi.org/10.1590/S0100-204X2002000700017.

Oliveira, M. A. J., Bovi, M. L. A., Machado, E. C., Gomes, M. M. A., Habermann, G. and Rodrigues, J. D. (2002). Photosynthesis, stomatal conductance and transpiration in peach palm under water stress. Scientia Agricola, 59, 59-63. http://dx.doi.org/10.1590/ S0103-90162002000100008.

Pinheiro, C. and Chaves, M. M. (2011). Photosynthesis and drought: can we make metabolic connections from available data? Journal of Experimental Botany, 62, 869-882. http://dx.doi.org/10.1093/jxb/erq340.

Pires, T. P., Santos, S. E., Kuki, K. N. and Motoike, S. Y. (2013). Ecophysiological traits of the macaw palm: a contribution towards the domestication of a novel oil crop. Industrial Crops and Products, 44, 200-210. http://dx.doi.org/10.1016/j.indcrop.2012.09.029.

Rufino, M. U. L., Medeiros-Costa, J. T., Silva, V. A. and Andrade, L. H. C. (2008). Knowledge and use of ouricuri (Syagrus coronata) and babaçu (Orbignya phalerata) in Buíque, PE, Brazil. Acta Botanica Brasilica, 22, 1141-1149. http://dx.doi.org/10.1590/S0102-33062008000400025.

Santos, M. G., Oliveira, M. T., Figueiredo, K. V., Falcão, H. M., Arruda, E., Almeida-Cortez, J., Sampaio, E. V. S. B., Ometto, J. P. H. B., Meneses, R. S. C., Oliveira, A. F. M., Pompelli, M. F. and Antonino, A. C. D. (2014). Caatinga, the Brazilian dry tropical forest: can it tolerate climate changes? Theoretical and Experimental Plant Physiology, 26, 83-99. http://dx.doi.org/10.1007/s40626-014-0008-0.

Scholander, P. F., Hammel, H. T., Hemmingsen, E. A. and Bradstreet, E. D. (1964). Hydrostatic pressure and osmotic potential in leaves of mangroves and some other plants. Proceedings of the National Academy of Sciences of the United States of America, 52, 119.

Suresh, K., Nagamani, C., Kantha, D. L. and Kumar, M. K. (2012). Changes in photosynthetic activity in five common hybrids of oil palm (Elaeis guineensis Jacq.) seedlings under water deficit. Photosynthetica, 50, 549-556. http://dx.doi.org/10.1007/ s11099-012-0062-2.

Tucci, M. L. S., Erismann, E. M., Machado, E. C. and Ribeiro, R. V. (2010). Diurnal and periodal variation in photosynthesis of peach palms grown under subtropical conditions. Photosynthetica, 48, 421-429. http://dx.doi.org/10.1007/s11099-010-0055-y. 